> Gi respons på artikler gjennom artiklenes kommentarfelt på tidsskriftet.no.

Innleggene publiseres fortløpende på Tidsskriftets nettside og et utvalg

av innleggene publiseres også i papirutgaven i spalten «Brev til redaktøren».

Redaksjonen forbeholder seg retten til å foreta redaksjonelle endringer.

Forfattere av vitenskapelige artikler har tilsvarsrett, jf. Vancouver-gruppens regler.

\section{Re: Skal feber hos intensivpasienter behandles?}

I Tidsskriftet nr. 3/2016 kommenterer kollega Tor-Inge Tønnesen HEAT-undersøkelsen som viste at paracetamol gitt til intensivpasienter med infeksjonsutløst feber ikke medførte kortere liggetid $i$ intensivavdelingen $(1,2)$. Heller ikke sekundære endepunkter; herunder død i intensivavdelingen eller etter 90 dager, ventilatortid, behov for nyreerstattende terapi, behov for vasoaktive legemidler eller liggetid i sykehuset, var påvirket av behandlingen. Derimot fant man at pasienter som overlevde intensivoppholdet hadde noe kortere liggetid i intensivavdelingen dersom de fikk paracetamol enn pasienter som fikk placebo (median liggetid 3.5 dager [IQR 1.9-6.9] vs. 4.3 dager [IQR 2.1-8.9], $\mathrm{P}=0.01$ ). Hos pasienter som ikke overlevde intensivoppholdet var forholdet motsatt: Pasienter som fikk paracetamol hadde vesentlig lengre liggetid i intensivavdelingen enn pasienter som fikk placebo (10.4 dager [IQR 4.1-16.9] vs. 4.0 dager [IQR 1.7 to 9.4$], \mathrm{P}<0.001)$.

I intervjuet med Tor-Inge Tønnessen står det at gjennomsnittlig temperaturforskjell mellom intervensjons- og placebogruppene var på bare 0,2 grader. I det publiserte appendikset til studien finner vi imidlertid kurver som viser at pasienter som fikk paracetamol fikk normalisert kroppstemperatur allerede en dag etter randomisering, og at kurvene ikke møtes før på dag 3. Dette kan kanskje forklare hvorfor paracetamol-behandlede overlevere hadde kortere liggetid enn placebo-behandlede - og omvendt, at pasienter som døde hadde lengre liggetid om de var paracetamol-behandlet enn pasienter som fikk placebo: Temperaturfall vil av helsepersonell oppfattes som bedring av pasientens kliniske tilstand, og vedvarende høy temperatur som at behandlingen ikke fører frem. Pasienter med normalisert temperatur blir derfor skrevet ut av avdelingen, mens pasienter med vedvarende høy temperatur blir liggende, selv om det ikke er behov for organunderstøttende behandling. Motsatt vil helsepersonell som behandler pasienter med fortsatt behov for organunderstøttende terapi og med vedvarende feber oppleve at pasienten ikke svarer på behandlingen, og kanskje avslutte denne tidligere enn hos pasienter med tilsvarende dårlig prognose, men der kroppstemperaturen er normalisert.

Mens hovedresultatene av studien kan gi inntrykk av at det er likegyldig om pasientene får paracetamol eller ikke, ser vi nå at endret kroppstemperatur kan ha vesentlig effekt på helsepersonells atferd. Fra før vet vi at livsavslutning i intensivavdelinger i svært stor grad er foranlediget av beslutninger om å avgrense eller avslutte behandlingstiltak (3). Det er i mindre grad kjent hvilke forhold som påvirker disse beslutningene. Hvorvidt man konkluderer at paracetamol har en gunstig eller ugunstig effekt på beslutningsprosessen avhenger nok av øynene som ser. Selv mener jeg at vesentlig forlenget liggetid hos pasienter som likevel dør i intensivavdelingen er et onde, mens marginalt kortere liggetid for pasienter som overlever bare utgjør en marginal gevinst. Etter denne undersøkelsen vil jeg derfor begrense paracetamol-bruken til mine pasienter.

\section{Jon Henrik Laake \\ jlaake@ous-hf.no}

Jon Henrik Laake (f. 1963) er spesialist i anestesiologi og overlege ved Akuttklinikken, Oslo universitetssykehus, Rikshospitalet.

Ingen oppgitte interessekonflikter.

\section{Litteratur}

1. Slagstad K. Skal feber hos intensivpasienter behandles? Tidsskr Nor Legeforen 2016: 136: 219.
2. Young $P$, Saxena M, Bellomo R et al; Australian and New Zealand intensive care society clinical trials group. Acetaminophen for fever in critically ill patients with suspected infection. N Engl J Med 2015; 373: 2215-24.

3. Sprung CL, Cohen SL, Sjokvist P et al; Ethicus Study Group. End-of-life practices in European intensive care units: the Ethicus Study. JAMA 2003; 290: $790-7$.

\section{Re: Skal feber hos intensivpasienter behandles?}

Kollega Jon Henrik Laake har kommet med interessante og viktige kommentarer til HEAT-studien som bemerkninger til et intervju med undertegnede om denne studien.

Forskjellen i gjennomsnittlig maksimaltemperatur mellom gruppen som ble randomisert til paracetamol vs. placebo var $0,2^{\circ} \mathrm{C}$ $\left(38,4+/-1,0^{\circ} \mathrm{C}\right.$ vs. $\left.38,6{ }^{\circ} \mathrm{C}\right)$ og gjennomsnittlig kroppstemperatur $\left(37,0^{\circ} \mathrm{C}\right.$ vs. $\left.37,3^{\circ} \mathrm{C}\right)$, figur S5 og S6 og tabell 8 i supplerende filer (1). Etter inklusjon falt temperaturen markant både i paracetamolog placebogruppen, sannsynligvis som uttrykk for at behandling med antibiotika hadde effekt i begge grupper. Gjennomsnittlig døgntemperatur falt noe mer i paracetamol-gruppen; på dag 0 var forskjellen mellom gruppene $0,3{ }^{\circ} \mathrm{C}\left(37,7^{\circ} \mathrm{C}\right.$ vs. $\left.37,4^{\circ} \mathrm{C}\right)$, på dag $1,0,5^{\circ} \mathrm{C}$ $\left(37,0^{\circ} \mathrm{C}\right.$ vs. $\left.37,5^{\circ} \mathrm{C}\right)$ og på dag $20,3{ }^{\circ} \mathrm{C}\left(37,2^{\circ} \mathrm{C}\right.$ vs. $\left.36,9^{\circ} \mathrm{C}\right)$, figur $\mathrm{S} 6$ i supplerende filer (1). Forskjellene mellom gruppene var signifikante, men ikke store. Det er verdt å merke seg at også placebogruppen nådde normaltemperatur i løpet av kort tid, og ikke hadde vedvarende høy temperatur selv om variansen i begge gruppene var stor.

Det var ingen forskjell mellom gruppene, verken i primærendepunkt (intensivfrie dager fram til dag 28) eller sekundærendepunkter. Sekundærendepunktet «liggetid i intensivavdelingen» viste heller ingen forskjell mellom gruppene, men i en subanalyse av de som overlevde versus de som døde fant en at paracetamol-gruppen hadde kortere liggetid hvis pasienten overlevde, mens paracetamolbehandlede som døde hadde lengre liggetid i intensivavdelingen. Dette var et sekundærendepunkt, og siden studiens statistiske styrke ikke primært var beregnet for dette endepunktet, kan forskjellen skyldes en type 1-feil. Imidlertid er liggetiden for pasienter som får paracetamol hos de som senere døde, betydelig lenger $(10,4$ dager (IQR 4,1-16,9)) enn de som fikk placebo $(4,0$ dager (IQR $1,7-9,4)$, og funnet virker derfor klinisk veldig relevant. Forklaringen som dr. Laake understreker og som forfatterne også tar opp i diskusjonsdelen av studien, nemlig at pasienter med lavere temperatur tidlig i forløpet vil fortere utskrives fordi de fremstår bedre, mens de sykeste pasientene som senere dør behandles lengre når temperaturene er lavere fordi den kliniske tilstanden virker bedre og leder til ytterligere behandling, er plausibel. Studien sier ikke noen om at årsaken til lengre liggetid er redusert temperatur, andre biologiske effekter av paracetamol eller helsepersonells tolkning av redusert temperatur som et tegn på bedre prognose. Å avgrense eller avslutte behandlingstiltak er krevende og kompliserte prosesser som bygger på helhetlige bedømmelser av pasientenes tilstander og prognoser. Om en moderat nedgang i temperatur vil bidra til disse avgjørelsene er denne studiene selvfølgelig ikke i stand til å si noe om. Men funnet er hypotesegenererende og kan testes i fremtidige studier. Om dette skal avstedkomme begrenset paracetamolbruk til intensivpasienter er en interessant diskusjon som også forfatterne av studien, både Paul Young og Rinaldo Bellomo, har tatt opp på flere intensivkonferanser etter at studien ble publisert. Dette er en pågående diskusjon i intensivmiljøet, og siste ord er ikke sagt. Jeg er imidlertid enig med Jon Henrik Laake at terskelen for bruk av paracetamol er hevet etter denne studien. 
Studien svarer derimot klart på at det ikke var økt forekomst av bivirkninger i paracetamol-gruppen, heller ikke en fryktet bivirkning som leverskade (faktisk var det noe økt forekomst av leverpatologi i placebogruppen), så fra et sikkerhetssynspunkt med tanke på bivirkninger er det trygt å bruke paracetamol for symptomlindring hos intensivpasienter.

\section{Tor Inge Tønnessen \\ t.i.tonnessen@medisin.uio.no}

Tor Inge Tønnessen (f. 1956) er professor og overlege ved Intensivavdelingen ved Oslo universitetssykehus.

Ingen oppgitte interessekonflikter.

Litteratur

1. Young P, Saxena M, Bellomo R et al; Australian and New Zealand Intensive Care Society Clinical Trials Group. Acetaminophen for Fever in Critically III Patients with Suspected Infection. N Engl J Med 2015: 373: 2215-24.

\section{Re: En mann i 60-årene med akutte ryggsmerter og nyresvikt}

Takk for en interessant og spennende pasienthistorie som minner oss om viktigheten av samarbeid på tvers av ulike spesialitetere (1). I artikkelen poengteres det hva en fastlege bør undersøke og gjøre, for at hastegrad og «adresse» på en henvisning skal bli riktig. Men er det rimelig å avvise en henvisning til en radiologisk undersøkelse ut ifra at pasientens kliniske tilstand ikke var forenlig med nyrekreft og at en nefrolog burde vurdere pasienten først?

Det første en nefrolog vil ønske å vite er sannsynligvis: foreligger det en postrenal nyresvikt? Dette ville raskt blitt avklart med enten utralyd ellet CT av nyrer/urinveier. Dersom man mener det ikke er indikasjon for en CT-nyrer ved en nyoppdaget nyresvikt burde man i alle fall vurdere å gjøre henvisningen om til en ultralyd nyrer - i så fall hadde mange ukers forsinkelse vært unngått.

Enhver lege som mottar en henvendelse eller henvisning fra en kollega bør ta høyde for at ikke all viktig informasjon nødvendigvis foreligger - for eksempel er det ikke lett å være sikker på at en nyresvikt er akutt dersom pasienten kun har tatt én kreatininverdi. Etter min mening kan ikke alt ansvar legges på fastlegen som kanskje har anført «akutt nyresvikt» på henvisningen, uten å ha full dekning for det. Legen som mottar en henvisning bør også gjøre sine vurderinger og lese «mellom linjene», så det kommer pasientene våre til gode.

\section{Thomas Schwartz}

thomas.schwartz@medisin.uio.no

Thomas Schwartz (f. 1960) er LIS i indremedisin ved Oslo universitetssykehus, Ullevål.

Ingen oppgitte interessekonflikter.

Litteratur

1. Konradsen S, Mathisen T, Haro S. En mann i 60-årene med akutte ryggsmerter og nyresvikt. Tidsskr Nor Legeforen 2016; 136: 139-41.

\section{S. Konradsen og medarbeidere svarer:}

Vi vil takke Schwartz for hans kommentar. Den bidrar til å utdype et av hovedpoengene $i$ artikkelen vår. Allmennmedisinen er full av usikkerhet, og ofte tas beslutninger basert på usikre symptomer og funn. God samhandling mellom sykehusleger og allmennleger vil derfor enkelte ganger innebære at sykehuslegen endrer foreslått utredningsforløp basert på opplysningene i henvisningen. I vårt tilfelle mener vi at radiolog selv kunne ha endret modalitet til ultralyd nyrer utfra opplysningene i henvisningen (nyresvikt, anemi uten opplysning om hematuri) slik at forsinkelse i utredningen kunne vært unngått.
Meningen med artikkelen var, foruten å sette fokus på manglende informasjonsutveksling mellom primær- og spesialisthelsetjeneste, å illustrere viktigheten av ansvaret hvert enkelt ledd i helsevesenet har. Det var ikke vår intensjon å gjøre noen til syndebukk.

\section{Steinar Konradsen \\ Steinarkonradsen@yahoo.no \\ Tommy Mathisen \\ Sergio Haro}

Steinar Konradsen (f. 1981) er lege i spesialisering ved Intermediæravdelingen, DMS Midt-Troms.

Ingen oppgitte interessekonflikter.

Tommy Mathisen (f. 1976) er cand.med. og konsulent.

Ingen oppgitte interessekonflikter.

Sergio Haro (f. 1957) er spesialist i generell kirurgi og i urologi og er overlege.

Ingen oppgitte interessekonflikter.

\section{Re: Et ulogisk og uheldig bivirkningsbegrep}

Jeg har ikke på noen måte ment å så tvil om Slørdal \& Christoffersens kliniske engasjement (1). Men vi preges alle av vårt ståsted, og jeg synes det ville være rart om de to som professorer i klinisk farmakologi, med ansvar for forskning og undervisning i faget, ikke er «mer opptatt av legemidlenes egne bivirkninger i anbefalte doser» enn oss som har andre ståsteder. Jeg synes det er både naturlig og prisverdig.

Men det vi vel alle er mest opptatt av er at alle legemidler brukes på en slik måte at pasientene får den aller beste behandling. $\mathrm{Og}$ da må hensynet til sikkerhet veies opp mot faren for forsinket diagnose, og at pasientene blir redd for å bruke de mest egnede legemidler pga beskrivelse av mange og tildels farlige bivirkninger.

Jeg er glad for at Slørdal \& Christoffersen er enig med meg $i$ at beskrivelsene av legemiddelbivirkninger ofte er uhensiktsmessige. Det har vært tilfellet lenge før den nye definisjonen ble lansert, og jeg er enig $i$ at den utvidede definisjonen vil forverre situasjonen hvis det ikke gjøres noe med beskrivelsene. For mye informasjon blir fort dårlig informasjon - det vesentlige drukner i det uvesentlige.

Mitt innlegg var et forsøk på å få debattantene til å gå sammen om å bedre beskrivelsene av legemiddelbivirkninger på bakgrunn av det endrete bivirkningsbegrepet.

Kan utvidelsen i bivirkningsdefinisjonen beskrives under et nytt avsnitt som for eksempel kan kalles «Uheldige virkninger ved feilbehandling»? Da vil vel bivirkningsavsnittet bli uendret. Og kan de usikre ikke-signifikante bivirkningene etter den gamle definisjonen beskrives under en egen overskrift i bivirkningsavsnittet som for eksempel: «Bivirkninger uten sikker signifikans» eller mer presist: «Bivirkninger/symptomer hvor forekomsten i sammenlignbare pasientgrupper er ukjent»?

Det er jo mye lettere å få endret de norske beskrivelsene enn å endre et EU-vedtak. Det ville være fint om Legemiddelverket kunne svare på dette.

\section{Jon Haffner}

Jon.Haffner@gmail.com

Jon Haffner (f. 1940) er pensjonert kirurg.

Ingen oppgitte interessekonflikter.

\section{Litteratur}

1. Slørdal L, Christoffersen T. Re: Et ulogisk og uhensiktsmessig bivirkningsbegrep. Tidsskr Nor Legeforen 2016; 136: 292 